
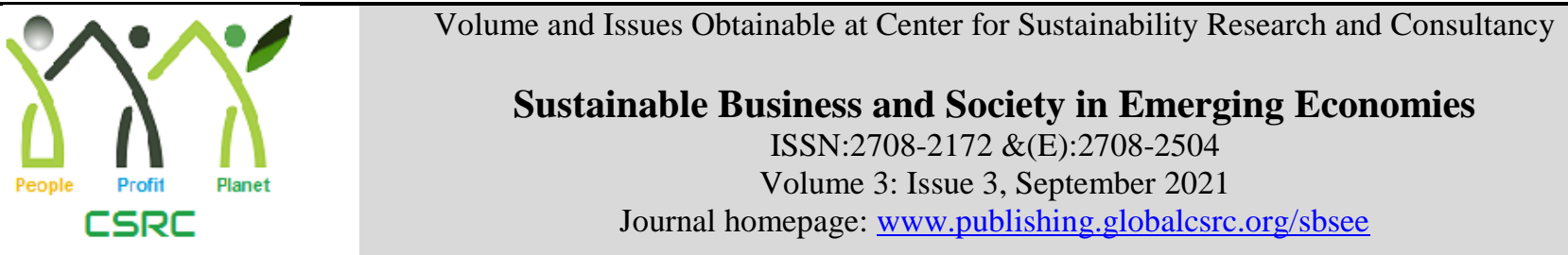

\title{
Abrogation of Article 370 and the Media Framing of Kashmir Conflict: A Pursuit for Re-conciliatory Approach
}

Ayesha Siddiqua, Department of Mass Communication, National University of Modern Languages, Islamabad, Pakistan

Khalid Sultan, Department of Mass Communication, National University of Modern Languages, Islamabad, Pakistan

Atif Ashraf, Faculty of Media and Communication Studies, University of Central Punjab, Lahore, Pakistan

*Ghulam Shabir, Faculty of Media and Communication Studies, University of Central Punjab, Lahore, Pakistan

*Corresponding author's email: drshabir@yahoo.com, ghulam.shabir@ucp.edu.pk

ARTICLEDETAILS

History

Revised format: Aug 2021

Available Online: Sep 2021

\section{Keywords}

Abrogation of Article 370,

Jammu and Kashmir

Conflict, Peace Journalism,

War Journalism, Conflict,

Framing

JEL Classification

L80, L82
ABSTRACT

Objective: The study at hand attempts to analyze the media framing of $\mathrm{J} \& \mathrm{~K}$ conflict in the context of abrogation of Article 370 along with comprehending the extent to which ideals of peace journalism can be translated into journalistic practices.

Methodology: Quantitative analysis of the news items published in Dawn and The Nation (Pakistani media); Times of India and The Hindu (Indian media) indicated that the media framing of Kashmir conflict by the all four selected English dailies from India and Pakistan was heavily dominated by war framing.

Findings: Findings of the qualitative interviews conducted from the Indian and Pakistani journalists indicated that the ideals of peace journalism can be translated in to journalistic practices by not justifying human rights violations and by focusing on more in-depth coverage of less visible effects of conflict. A search for common grounds among key stake holders and refraining from becoming part of propaganda were among other key factors which can play a vital role in practicing peace journalism.

Implications: Peace Journalism can be understood as a special form of responsible journalism as it has the potential to contribute in the peace process.

(C2021 The authors, under a Creative Commons Attribution- Non Commercial- 4.0

Recommended citation: Siddiqua, A., Sultan, K., Ashraf, A. and Shabir, G. (2021). Abrogation of Article 370 and the Media Framing of Kashmir Conflict: A pursuit for Re-conciliatory Approach. Sustainable Business and Society in Emerging Economies, 3 (3), 149-162.

\section{Introduction}

The violent conflict brewing in the Indian administered Valley of Jammu and Kashmir (J\&K) has repeatedly played a decisive role in defining the diplomatic relations between geographically bound 
traditional rivals, India and Pakistan. The magnitude of the conflict has evolved from a regional conflict to an international conflict as it enjoys the capability of drawing two nuclear powers towards a nuclear war (Nixxon, 1992).

Kashmir is located in the Himalayan range of mountains and is also the origin point of many rivers in the South Asian region. Geographically Kashmir is surrounded by India, Pakistan and China. India administers about 45 percent of Kashmir's total area; Pakistan administers about 35 percent of Kashmir's total area whereas China administers about 20 percent of Kashmir's total area (Bukhari \& Parveen, 2014). J\&K conflict is considered to be a concern for international peace as it has frequently triggered ethnic outbreaks, severe human rights violations and cross border terrorism including Line of Control violations in the region. On October 31, 2019 India formally divided the Indian administered Kashmir into two federally administered territories as an implication of the abrogation of Article 370. Both Jammu and Kashmir were combined into one territory and named as Jammu whereas Ladakh area bordering with China was made a separate territory (Gupta, 2019).

Number of scholars including (Manoff, 1998, 2004; Bar-Tal, 2000; Carruthers, 2000; Wolfsfeld , 2004) suggested that the media coverage of conflict was mostly destructive but still an alternative and unconventional approach by media could not be negated altogether. Peace Journalism surfaced as an alternative way of reporting in which the journalists "care as well as know" (Bell, 1998:p.16) and in which the notions of responsibility and accountability goes hand in hand (Howard, 2003). The media coverage of Jammu and Kashmir in the context of conflict resolution and peace and war journalism has been a subject of interest for journalists and scholars alike (Sonwalker, 2005; Sreedharan, 2009; Cheema, 2015). As a result of major escalation in the Kashmir conflict after the abrogation of Article 370 of the Indian Constitution, the study at hand analyzed the coverage of J\&K conflict through the perspective of peace and war journalism along with comprehending the extent to which ideals of peace journalism can be translated to journalistic practices. Content analysis of the news stories published in the Pakistani and Indian English press was carried out for investigating the war and peace journalism framing trends. Dawn and The Nation which are highly circulated English dailies of Pakistan (Press Reference, 2009) were selected from the Pakistani English Press. Times of India and The Hindu which are considered to be among the highly circulated and influential English dailies of India (Kaushal, 1997; Viswanath \& Karan , 2000) were selected from the Indian English Press. The study also attempted to explore that how the ideals of peace journalism can be translated to journalistic practices. The nature of the study called for an exploratory approach along with the descriptive analysis of the news stories published in the selected press. The exploratory perspectives of the study were entertained through the method of in-depth interviews of Pakistani and Indian journalists.

The study is significant as the abrogation of Article 370 has not only altered the geographical status of $\mathrm{J} \& \mathrm{~K}$ but has also put the stability of the whole South Asian region at an unprecedented risk. The ruling political party of India Bharatiya Janata Party (BJP) has advocated the idea of stripping the disputed Kashmir from its special status since decades and Pakistan's outrage on the matter has intensified the heated rhetoric (Chandrachud, 2019). In an evolving conflict scenario the role of journalists and their journalistic choices can help in developing prospects for society to reflect on non-violent reactions.

\section{Background of Kashmir Conflict}

Kashmir conflict is considered to be an unresolved agenda of the subcontinent partition which took place in 1947. In recent past the serene valley of Jammu and Kashmir had witnessed an armed uprising since 1989 (Bukhari, 2016). The year 2016 witnessed an intense violent wave in the valley. The leader of PDP (People's Democratic Party) Mehbooba Mufti took oath as the first female Chief Minister of Jammu and Kashmir in April 2016. The death of Mufti Muhammad Sayeed in January 2016 paved way for the power struggle between Mehbooba Mufti, a law graduate and the ruling Bharatiya Janata Party (Bukhari \& Masroor, 2016). The Indian government wanted a new industrial policy in Jammu and Kashmir as a result of which non-locals would be allowed to acquire large areas of land in the valley. Therefore the 
government of Bharatiya Janata Party in India forcefully supported the resettlement of Hindu Pandits in the valley through the establishment of Sainik Colonies in May 2016 (The Indian Express, 2016). The issue of Sainik colony was still developing as a 22-year old separatist fighter from an upper class educated Kashmiri family, Burhan Wani was killed on July 8, 2016 (Bukhari, 2016). Wani was killed along with his two companions by the Indian Security forces. He revitalized the orthodox forms of demonstrations and protests by effectively employing social media platforms (Dasgupta, 2016). Wani's social media outreach created a stir both in the youth of Kashmir, which makes around $60 \%$ of the valley's population and in the Indian and Pakistani media. He was referred to as the poster boy of Kashmir and had a bounty of one million rupees on his arrest (Rao, 2016). Killing of Burhan Wani had an intense impact on the Valley's political, economic and security situation in terms of demonstrations by Kashmiris and longest imposed curfew by the Indian security forces. Wani relished impressive amount of support from Kashmiris both in his life and death because of four major reasons (i) armed rebels like Wani did not target civilians; (ii) they functioned independently without seeking foreign support; (iii) they choose a moderate path through welcoming Hindu pilgrims and favoring the return of migrant Kashmiri Pandits to their homes; (iv) their rebelliousness had a symbolic significance for the Kashmiri population (Geelani, 2016). Burhan Wani's killing was followed by intense anti-Indian demonstrations across Jammu and Kashmir. Curfew was enforced in all districts of Jammu and Kashmir on $15^{\text {th }}$ July 2016 which kept in force for 53 consecutive days and was lifted on $31^{\text {st }}$ August but was again reinforced the next day (Khurshid, 2016).

In the wake of anti-state riots the heavy use of pellet guns by the Indian Security Forces made the situation more intense and violent. The photographs of severely injured and blinded civilians including women and children as a result of the excessive use of pellet guns stimulated an international reaction. Eye injuries were reportedly sustained by more than 1000 civilians (The Indian Express, 2016). The victimization of children was intensely criticized because " $14 \%$ of pellet gun victims in Kashmir were below the age of 15" ( Ashiq, 2016). On September 18, 2016 near the de facto Pak-India border an Indian army base was attacked at Uri in Kashmir. India accused Pakistan of facilitating the attack which was executed by four fully armed militants and resulted in the death of 18 Indian soldiers (Ahmed, Philips, \& Berlinger, 2016). The Uri attack initiated a more intensified blame game between India and Pakistan.

The role of Kashmiri politicians in the post Burhan Wani incident grew more anti India. On the other hand the policies imposed by the BJP led government in the center increased the gap between the Kashmiri public and the rest of the world. The unrest which engulfed the valley during Wani episode transformed into a devastating situation when the Indian Primer Narendra Modi during his Speech on August 15, 2019 announced his government's step to strip Kashmir from the autonomous status in terms of abrogating the Article 370 of the Indian constitution.

\section{Abrogation of Article 370}

The abrogation of Article 370 was considered to be one of the key demands by the Hindu Nationalists dating back to as early as 1950s. The autonomy of Indian Occupied Kashmir has been partially taken away through a number of policies implemented by the Indian government during the 1950s and 1960s. It was majorly after the mid-1960s that only certain symbolic parts of Article 370 were left intact which included a separate state flag, a separate state constitution with almost no actual significance and a state penal code (Bose, 2019). Article 35A was also left intact as it assured job opportunities on priority basis to the local residents along with preventing outsiders from buying land in the valley. The provisions provided in the Article 35A were not unique to the Indian administered Kashmir only as other Indian states including Uttarakhand, Himachal Pardesh, Punjab and some north-eastern states of India also provided similar provisions to the native population. The reason for dividing the Kashmiri state into union territories was rooted in the Indian constitutional framework which provided more powers to the states in comparison to the unions (Bose, 2019). 
The limited autonomy of Jammu and Kashmir which was granted through Article 370 of the Indian Constitution was revoked by the Indian government on August 5, 2019. On October 31, 2019 India formally divided the Indian Occupied Kashmir into two federally administered territories as an implication of the abrogation of Article 370. Both Jammu and Kashmir were combined into one territory and named as Jammu. Originally Jammu was dominated by Hindus and comprised a population of about six million whereas Kashmir was a predominantly Muslim majority area and comprised of about eight million people. Ladakh area bordering with China has been made a separate territory with a population of about 300,000 with almost equal number of Buddhists and Muslims. R. K. Mathur was made the Lieutenant Governor of Ladakh whereas Girish Chandra Murmu sworn in as the Lieutenant Governor of Jammu and Kashmir regions ("Jammu and Kashmir: India formally divides flashpoint state", 2019). Both the infant union territories would be ruled directly through Delhi. It is not only the Muslim population which had felt deeply alienated and subjugated at the abrogation of Article 370 but the Buddhist population dominating the eastern Ladakh district, Leh also felt betrayed on losing their rights incurred by article 35A. In the true democratic sense India took an extremely undemocratic step by dividing $\mathrm{J} \& \mathrm{~K}$ in to two federation units. As India is comprised of voluntary federation of states it is undemocratic to force people of certain demographic region to be governed by the Center (Gupta, 2019).

India made a commitment to United Nations for holding a plebiscite in J\&K as per the UNSC 1947-48 resolution. India justified its failure to fulfill the commitment because Pakistan did not fully withdraw its forces from Kashmir (Gupta, 2019). In August 2019 the UN Secretary General Antonio Guterres made an appeal for "maximum restraint" through an official statement. He reinforced the significance of 1972 agreement, also termed as the Simla Accord according to which the conflict of Jammu and Kashmir must be settled through peaceful means (UN News, 2019). As per the Simla Agreement all problems between India and Pakistan were to be considered as bilateral and both the countries cannot take any territory by the use of force. As a result of the Simla Agreement the then CFL (Cease Fire Line) was renamed as LoC (Line of Control). Annulment of Article 370 broke the post Simla accord status quo. Resultantly Kashmir went through a more dangerous and permanent status quo after the scrapping of Article 370 as it was expected from both India and Pakistan to accept the existing borders as permanent.

The alarming situation of human rights condition in the Indian administered Kashmir is widely attributed to the scrapping of Article 370 by the BJP led Indian government. The valley witnessed continuation of protests as numerous Kashmiris were detained by the Indian state. "Thousands of people including three former Chief Ministers of the state were detained" to curtail resistance against the Indian policies ("Jammu and Kashmir: India formally divides flashpoint", 2019). The mobile services remained suspended for more than 72 days after stripping the Kashmir of its autonomous status. Internet services were suspended for indefinite period of time and most of the businesses also remained closed. The closure of businesses was attributed to both protests against governments and also to the fright of retaliations from separatist fighters who were against the Indian rule ("Jammu and Kashmir: India formally divides flashpoint", 2019).

On international forum a visit by the right wing European parliamentarians (MEPs) to the Indian administered Kashmir on $29^{\text {th }}$ October 2019 received criticism for being a "PR stunt". The visit helped in reestablishing the centuries old mantra that conflicts and the most worst of human rights violations can be masked through goodwill marketing and state propaganda. The EU parliament termed the visit as not an official one rather as a one conducted in the personal capacity of the MEPs. An MEP from the Liberal Democrat party of UK, Chris Davies's invitation was withdrawn after his demand to "go anywhere and talk to anyone he wanted" ("Outrage over right-wing Euro-MPs' Kashmir visit", 2019). After the abrogation of Article 370 it was the first visit of any international delegation to the region as even the Indian politicians were not allowed to visit the area. BJP's policies were compared to what Milosevic of Serbia did in Kosovo by unilaterally revoking its autonomy in 1989 and by imposing a police state on the Albanian majority population of Kosovo (Bose, 2019). 
The crisis in Kashmir halted all areas of social life including education as " 1.5 million Kashmiri children remained out of school" even 13 weeks after India's unilateral decision to revoke Kashmir's autonomous status (Yasir \& Gettleman, 2019). All private and government schools of the valley were shut down as the parents were fearful of sending their children to school in the presence of troops and separatist fighters spread across the valley. Parents were afraid that the bus carrying their children would be attacked by the anti-state actors or the faces of their children will be shot by pellets by the state security forces. Among the less discussed outcomes of an armed conflict are the psychological and social traumas which are especially faced by the youth of the conflict ridden areas. The current generation of Kashmiri children is considered to be amongst the most affected ones as they have not only witnessed the brutal killings of their families and friends but also the extreme feelings of vulnerability and depression (Yasir \& Gettleman, 2019).

\section{Peace \& War Journalism}

Media framing of conflicts cannot be fully grasped without incorporating the framework of peace and war journalism. Framing itself can be described as the practice of developing news content factually yet thematically in order to communicate the key agenda of the story (Maslog et al , 2006). Tankard (1991, p.3) defined framing as the "fundamental organizing idea for news content that supplies a context and suggests what the issue is". The selected frames did not only help in terms of giving prominence to certain parts of information but also helps in making it more significant and salient for the audience (Shaw et al, 1997).

Scholars and academicians including Bell (1998); Galtung (1985, 1986, 1998); Lynch \& McGoldrick (2005); Tehranian (2002) sought alternate ways of reporting and humanizing conflicts. Peace Journalism draws its support from peace in comparison to violence; truth in comparison to propaganda; independent humans and individuals in comparison to the elite; and solution in comparison to victory or defeat. Peace journalism is referred to as a set of tools aimed at equipping journalists in terms of offering a better public service (Lynch and McGoldrick, 2005, p.5). Peace journalism is a form of reporting which has a more serious and professional approach in terms of reporting conflicts (Lynch \& Galtung, 2010, p.17). Dependence on subjective insights of reporters is supported by peace journalism as journalists are not expected to stick to ideas of objectivity (Wolfe \& Johnson, 1990).

The classification of peace and war journalism by Galtung also took language in to context as the use of negative words in terms of victimization and persecution are not encouraged in peace journalism. Peace journalism promotes a resolution based advocacy method in conflict reporting not only through the formation of news stories but also through the choices which reporters and journalists practice which helps in developing non-violent diagnoses for society. Ad vocative approach also concentrated on emphasizing less visible aspects of violence along with searching for common grounds (Maslog et al, 2006: p.23). Lynch \& McGoldrick (2005) presented peace journalism as a more logical, accurate and broader method of covering conflicts.

Galtung's (1998) views were further extended by McGoldrick and Lynch (2000) into 17 practices of peace journalism. The practices comprised of offering solutions, reporting about long-term effects, humanizing the conflict, probing for common grounds, reporting versions of all involved stakeholders, and using accurate language. Manoff (1998) focused on 12 productive roles of the media which can be employed while reporting violent conflicts. The roles were in compliance with the classification laid out by McGoldrick and Lynch (2000). The major roles included communication among opposing parties; educating on various aspects of conflict; building relationships; neutralizing misperceptions ; classifying the hidden interests; promoting balance of power; and seeking solutions (Manoff, 1998). 


\section{Kashmir in Media}

The framing of the Indo-Pak conflict with reference to Jammu \& Kashmir has been extensively covered by researchers and academicians (Cheema , 2015; Sreedharan , 2009; Zaheer , 2017). Galtung's classification was employed by Lee et al (2004) to examine the peace and war framing of four Asian regional conflicts. The coverage of Kashmir conflict by the Pakistani and Indian print media represented the strongest war framing among the four selected conflicts. Siraj (2008) examined the peace and war framing of Indo-Pak conflict in the elite US press. It was concluded that the number of war stories were greater in number than the number of peace stories or neutral stories regarding Indo-Pak conflict. The classification included "visible vs. invisible effects; difference oriented vs. solution oriented; here and now vs. causes and consequences; good and bad guy labeling vs. avoidance of labeling; two party orientation vs. multi-party orientation; partisan vs. non-partisan; elite-oriented vs. people oriented; use of demonizing language vs. avoidance of demonizing language” (Galtung, 1986, 1998).

Sreedharan (2009) also examined the coverage of Kashmir in the Indian and Pakistani press and concluded that the media of both the countries rendered negative and anti-peace coverage to the Kashmir conflict and also to each other. Sreedharan (2009) further stated that "newspapers on both sides were partisan in how they presented the conflict to their publics, clearly setting it out as an us-versus-them issue in which 'we' were the victims and 'they' the perpetrators of violence" (Sreedharan, 2009: p. 219).

The manner in which conflicts are reported by the media and the way it defined and redefined public sphere has been a matter of special interest for academicians and journalists alike. According to McCombs and Shaw (1972) mass communication has the power to affect and change perceptions and knowledge of public which is done through the process of framing. The notions of agenda setting and framing do not only affect the process of public opinion formation but also has influence on journalists' prejudices and perceptions in terms of interpreting the conflict scenarios (Aslam, 2014). Media not only made the audience aware about the public issues but also dictated it how much importance should be given to an issue or matter (Brosius \& Weimann, 1996). Media therefore played an important role in conflict situations. Thus the role of press and media both in terms of escalation or de-escalation of conflict is largely dependent on the framing along with the peace and war approach used by the journalists.

\section{Methodology}

The study was aimed at investigating the coverage of Kashmir conflict in the contemporary mainstream English press of Pakistan and India in the context of peace and war journalism. The method of content analysis was employed to analyze the press coverage of Kashmir conflict. The news items published in Dawn and the Nation from Pakistani press; Daily Times of India and Daily the Hindu from Indian press were selected for the purpose of content analysis. News stories published regarding the Kashmir conflict after the abrogation of article 370 were selected for the purpose of the study. The time period ranged from August 06, 2019 to August 06, 2020 as the abrogation of Article 370 from the Indian constitution took place on August 05, 2019. The stories were retrieved from both Lexus Nexus and the online archival data available on the websites of the selected dailies. The key words of "Jammu \& Kashmir Conflict"; "Abrogation of Article 370" and "Scrapping of Article 370" were used for retrieving the data. After removal of the duplicated news items a total of 334 news items were retrieved. It was through using a skip interval of one that a sample of 167 stories was selected through systematic random sampling.

Four separate frames of peace and war journalism were operationalized in the light of the available literature on media framing of conflicts (Gultung 1986, 1998; Lynch \& McGoldrick, 2005; Sreedharan 2009). The frames are operationalized in Figure 01. Every individual story was considered as the contextual unit whereas every paragraph was considered as the coding unit. The story was coded as peace journalism story or war journalism story depending upon the majority number of peace or war indicators in the story. If the number of peace and war frames were equal in a story it was coded as 
neutral. The statistical unit of analysis for this study was every individual news story. A coding sheet was developed for content analysis in light of the operationalization of frames mentioned in Figure- 01.

Figure-01 Operationalization of Frames

\begin{tabular}{l|l} 
Peace frames & War frames \\
\hline $\begin{array}{l}\text { Peace oriented: facts and aspects supporting conflict } \\
\text { resolution are highlighted in the story in comparison to } \\
\text { facts and aspects related to violence and aggression }\end{array}$ & $\begin{array}{l}\text { Violence oriented: facts and aspects related to violent } \\
\text { events of conflict are highlighted in the story in } \\
\text { comparison to less violent responses to conflict }\end{array}$ \\
\hline $\begin{array}{l}\text { Truth Oriented: points of view of more than one or all } \\
\text { stake holders with competing interests are included in } \\
\text { the story }\end{array}$ & $\begin{array}{l}\text { Propaganda Oriented: points of view of one stake } \\
\text { holder are propagated as the only available and justified } \\
\text { point of view }\end{array}$ \\
\hline $\begin{array}{l}\text { Multiple Source Oriented: Information derived from } \\
\text { independent sources and first hand versions of witnesses } \\
\text { are also incorporated in the story }\end{array}$ & $\begin{array}{l}\text { Elite Source Oriented: Information and versions of } \\
\text { only elite sources like military and bureaucracy are } \\
\text { incorporated in the story }\end{array}$ \\
\hline $\begin{array}{l}\text { Solution Oriented: Points of view of all stakeholders } \\
\text { especially with reference to less or non-violent responses } \\
\text { to conflict are covered and highlighted }\end{array}$ & $\begin{array}{l}\text { Zero-sum oriented: Point of view of one of the } \\
\text { stakeholders is covered and highlighted to present that } \\
\text { particular stakeholder at the winning end of the conflict }\end{array}$ \\
\hline
\end{tabular}

Neutral Frames: If the number of war and peace frames were equal in a story it was coded as neutral

The study also attempted to explore the extent to which the ideals of peace journalism can be translated in to journalistic practices by the journalists. For this exploratory angle the method of qualitative indepth interviews was employed. A total of 10 journalists from Pakistan and India were purposively selected for in depth interviews. Semi structured interviews were conducted from mid-career and senior Indian and Pakistani journalists who had 5 or more years of experience in covering Kashmir conflict and diplomatic relations between India and Pakistan. The interviews were conducted through Skype. Notes were taken during the interviews.

\section{Research Questions}

1- To what extent the coverage of Kashmir conflict is dominated by peace or war framing after the abrogation of Article 370?

2- To what extent it is possible to translate the ideals of peace journalism in to journalistic practices?

\section{Results and Discussion}

1- To what extent the coverage of Kashmir conflict is dominated by peace or war framing after the abrogation of Article 370?

Table-01 Frequency of Retrieved News stories

\begin{tabular}{lc}
\hline Newspaper & Frequency of stories \\
\hline Dawn & $38(22.75 \%)$ \\
The Nation & $38(22.75 \%)$ \\
Times of India & $39(23.35 \%)$ \\
The Hindu & $52(31.17 \%)$ \\
\hline Total & $167(100 \%)$ \\
\hline
\end{tabular}

Table-01 shows the frequency of news stories which appeared in the selected newspapers. A total of 38 
stories were selected from Dawn which comprised of $22.75 \%$ of the total number of stories. 38 stories were selected from the Nation which also made $22.75 \%$ of the total data. A total of 39 stories were selected from the Times of India which comprised of $23.35 \%$ of the total data. A total of 52 stories were selected from The Hindu which comprised of $31.17 \%$ of the total data.

\begin{tabular}{|c|c|c|}
\hline \multicolumn{3}{|c|}{ Table-02: Frequency of Source of Story } \\
\hline Source of Story & Frequency & Percentage \\
\hline Staff Reporter & 47 & $28.14 \%$ \\
\hline News Agencies & 50 & $29.94 \%$ \\
\hline $\begin{array}{ll}\text { Local } & \text { Correspondents/ } \\
\text { Freelancers } & \\
\end{array}$ & 42 & $25.15 \%$ \\
\hline $\begin{array}{lll}\begin{array}{l}\text { Reprinted } \\
\text { publications }\end{array} & \text { from } & \text { other } \\
\end{array}$ & 20 & $11.97 \%$ \\
\hline Others & 8 & $4.79 \%$ \\
\hline Total & 167 & $100 \%$ \\
\hline
\end{tabular}

Out of 167 total selected news stories 47 were filed by staff reporters; 50 stories were based on the information filed through news agencies; 42 stories were filed through local correspondents; 20 were reprinted from other publications and 8 stories were filed through other sources.

Table-03 Distribution of Stories by War Journalism Frames

\begin{tabular}{lllll}
\hline War Journalism & Dawn & The Nation & Times of India & The Hindu \\
\hline $\begin{array}{l}\text { Violence } \\
\text { Oriented }\end{array}$ & $20(52.63 \%)$ & $30(78.95 \%)$ & $36(92.30 \%)$ & $35(66.30 \%)$ \\
$\begin{array}{l}\text { Propaganda } \\
\text { Oriented }\end{array}$ & $23(60.52 \%)$ & $30(78.95 \%)$ & $36(92.30 \%)$ & $35(66.30 \%)$ \\
$\begin{array}{l}\text { Elite source } \\
\text { Oriented }\end{array}$ & $19(50 \%)$ & $30(78.95 \%)$ & $34(87.17 \%)$ & $35(66.30 \%)$ \\
$\begin{array}{l}\text { Zero-Sum } \\
\text { Oriented }\end{array}$ & $16(42.10 \%)$ & $29(76.31 \%)$ & $33(84.61 \%)$ & $34(65.38 \%)$ \\
$\begin{array}{l}\text { Total Stories } \\
\text { with majority } \\
\text { war journalism } \\
\text { frames }\end{array}$ & $23(60.52 \%)$ & $25(65.79 \%)$ & $28(71.79 \%)$ & $34(65.38 \%)$ \\
\hline
\end{tabular}

Table-03 illustrates that the highest percentage of stories with majority war journalism frames were reported in the Times of India followed by The Nation; The Hindu and Dawn. The results also indicated that majority of the stories in all selected English dailies of India and Pakistan was dominated by war frames.

Table-04 Distribution of Stories by Peace Journalism

\begin{tabular}{|c|c|c|c|c|}
\hline Peace Journalism & Dawn & The Nation & Times of India & The Hindu \\
\hline Peace Oriented & $14(36.84 \%)$ & $4(10.52 \%)$ & $3(7.69 \%)$ & $13(25.0 \%)$ \\
\hline Truth Oriented & $11(28.94 \%)$ & $4(10.52 \%)$ & $3(7.69 \%)$ & $13(25.0 \%)$ \\
\hline $\begin{array}{l}\text { Multiple } \quad \text { source } \\
\text { oriented }\end{array}$ & $15(39.47 \%)$ & $4(10.52 \%)$ & $5(12.82 \%)$ & $13(25.0 \%)$ \\
\hline Solution Oriented & $18(47.36 \%)$ & $5(13.15 \%)$ & $6(15.38 \%)$ & $14(26.92 \%)$ \\
\hline $\begin{array}{l}\text { Total Stories with } \\
\text { majority peace } \\
\text { journalism frames }\end{array}$ & $11(28.94 \%)$ & $9(23.68 \%)$ & $11(28.20 \%)$ & $14(26.92 \%)$ \\
\hline
\end{tabular}

Table-04 shows that the highest percentage of peace oriented stories was recorded in Dawn, followed by 
Times of India, The Hindu and The Nation. Although the majority of news stories were covered through war framing but Dawn and Times of India took the lead in peace framing of the Kashmir conflict in comparison to the other selected press.

Table-05 Cross tabulation of Neutral Frames with Newspapers

\begin{tabular}{lllll}
\hline Neutral Frames & Dawn & The Nation & Times of India & The Hindu \\
\hline & & & & \\
\hline
\end{tabular}

Table-05 represents that the Dawn and The Nation recorded a higher percentage of neutral stories in comparison to The Hindu and Times of India.

The results of the content analysis indicated that the majority of the news framing of Kashmir conflict after the abrogation of Article 370 in the press of both the countries was done from the perspective of war framing. The results strengthened Gultung's $(1986,1998)$ views on war journalism as it draws its support from violence, propaganda, elite sources and zero-sum approach whereas peace journalism draws its support from peace in comparison to violence; truth in comparison to propaganda; independent humans in comparison to the elite; and solution in comparison to victory or defeat (Lynch and McGoldrick, 2005).

The significance of reporting during conflict and war becomes even more delicate as journalists consider themselves as soldiers whose responsibility is to work in hell so that they can record history (Pedelty 1995, p.29). McCombs and Shaw (1972) asserted that mass communication has the power to affect and change perceptions and knowledge of public which is done through the process of framing. The notions of agenda setting and framing had not only effects on the process of public opinion formation but also represented journalists' prejudices and perceptions in terms of interpreting the conflict scenarios (Aslam, 2014). Scheufele (1999) asserted that media frames are used by the journalists in order to disseminate information to the masses. It is also noted that the majority of the people who are exposed to specific frames are likely to be influenced by them (Lecheler \& De Vreese, 2011). Scheufele (1999) further asserted that journalists are also likely to be influenced by the frequently used frames on a particular issue. Thus the dominance of war framing regarding Kashmir conflict can also be attributed to the frequent exposure and of war framing by the journalists working across borders.

\section{2-To What Extent it is Possible to Translate the Ideals of Peace Journalism in to Journalistic Practices?}

Number of scholars like Manoff (1997, 1998); Carruthers (2000); Bar-Tal (2000); Moeller (2004) and Wolfsfeld (2004) suggested that the media coverage of conflict is mostly destructive but still an unconventional and alternative approach by media cannot be negated altogether. Peace Journalism surfaced as a way of reporting for reporters in which they care as well as know (Bell, 1998, p.16) and which carries the notions of responsibility and accountability together (Howard. 2003).

Respondents agreed that mostly the contention in war journalism is the narrative of victimhood in comparison to peace journalism which is a more logical and accurate way of reporting conflicts. In Indian press the Indian forces are portrayed as the victims and the Kashmiris as aggressors whereas in Pakistani perspective the narrative is vice versa. Gohar Gellani a Srinagar based journalist said that ideals of peace journalism can be achieved by not justifying human rights violations and also by not rationalizing the criminalization of "Kashmiris legitimate political opinion"( personal communication). Shumaila Jaffery, an Islamabad based journalist said that the resolution approach in terms of "peace journalism can be translated by focusing on more in depth, humanized and consistent coverage of Kashmir issue" (Personal Communication). Thus peace journalism can be referred to as a set of tools aimed at equipping journalists in terms of offering a better public service. 
Galtung's classification of peace and war journalism also took language in to context as the use of negative words in terms of victimization and persecution are not encouraged in peace journalism. Peace journalism promoted a resolution based advocacy method in conflict reporting through the choices of reporters and journalists which helps in developing non-violent diagnoses for society. Ad vocative approach also concentrated on emphasizing less visible aspects of violence along with searching for common grounds (Maslog et al, 2006). Sammar Abbas, an Islamabad based journalist asserted that opinion writings and post-facto writings can add to the public sphere perspective but it is through actual reporting choices that journalists can fully take advantage of the notions of peace journalism including a search for common grounds and covering the less obvious and less talked about aspects of violent conflicts (personal communication). Amber Shamsi, another Islamabad based international journalist said that the "focus of the media is less on the colossal human tragedy and political disaster that Kashmir is facing, and more on the States' nationalistic interests" (personal communication). Gohar Gillani recalled that even when Indian Army's Major Leetul Gogoi tied a Kashmiri civilian Farooq Dar to the bonnet of jeep and paraded him through several villages of central Kashmir's Budgam district for hours the focus in the Indian media was to give a clean chit to Gogoi. "His potential war crime was defended as an act performed in self-defense" (personal communication).

Jaskirat Singh, a New Delhi based journalist asserted that peace journalism can be utilized at best by ensuring that the journalists refrain from becoming part of propaganda paradigm (personal communication). Respondents agreed that in order to fully translate the ideals of peace journalism to practice the media need to step out of the nationalistic boundaries. Although they agreed that it has become all the more challenging after the abrogation of Article 370 which has resulted in the change in geographical boundaries of the Indian administered Kashmir. Respondents also agreed that prohibiting the dissemination of certain credible information as a result of declared or undeclared censorship policies on the part of the governments also results in hindering the practices of peace journalism.

In the scenario of conflict coverage, organizational policies and other mediating factors determine the framing and treatment of news related content along with its selection (Van Ginneken, 1998, cited in Carruthers 2000, p. 15). As mostly news gathering and production is dependent on bureaucracy in times of conflict (Schlesinger, 1987; Sigal, 1973) therefore instead of the journalists it is the policy makers and bureaucrats who decide that which aspects of the conflict are worth covering and also which specific journalist will cover them (Carruthers, 2000). Thus the ideals of peace journalism cannot be fully translated into practices of journalism until the policy makers at the state level are sensitized about the notions of peace journalism and its long term effects in terms of creating opportunities for society at large to consider and value non-violent responses to conflict (Maslog et al, 2006).

On a concluding note the results of the content analysis revealed that both Pakistani and Indian press employed war framing more dominantly in comparison to peace framing while reporting Kashmir conflict after the abrogation of article 370. Respondents agreed that the ideals of peace journalism can be translated in to journalistic practices by not justifying human rights violations and by focusing on more in depth coverage of less visible effects of Jammu and Kashmir conflict. A search for common grounds among key stake holders and refraining from becoming part of propaganda were among other key factors which can play a vital role in practicing peace journalism. Thus Peace Journalism can be understood as a special form of responsible journalism as it has the potential to contribute in the peace process. 


\section{References}

Aslam R (2014). The role of media in conflict: Integrating peace journalism in the journalism curriculum. Doctoral dissertation, Auckland University of Technology, New Zealand.

Ashiq P ( 2016) 14\% of pellet gun victims in Kashmir are below 15. The Hindu, 22 August, 2016. Available at https://www.thehindu.com/news/national/other-states/14-of pellet gun victims-inKashmir-are-below-15/article14583549.ece

Ahmed M ,Philips R and Berlinger J (2016) Soldiers killed in army base attack in Indian administered Kashmir. CNN, 19 Sep 2016. Available at: http://edition.cnn.com/2016/09/18/asia/india kashmirattack/index.html

Bar-Tal D (2000) From Intractable Conflict Through Conflict Resolution to Reconciliation: Psychological Analysis. Political Psychology 21 (2): 351-365

Bell M (1998) The journalism of attachment . Media Ethics. London: Routedge, pp. 15-22.

Bose S (2019) Has India pushed Kashmir to a point of no return? BBC, 13 Aug 2019.

Available at: https://www.bbc.com/news/world-asia-india 49316350

Bukhari SWH and Parveen MT (2014). China's approach towards Kashmir conflict:A viable solution. Journal of Professional Research in Social Sciences 1: 14-30.

Bukhari S ( 2016) Why the death of militant Burhan Wani has Kashmiris up in arms. BBC News, 11 July 2016. Available at: https://www.bbc.com/news/world-asia-india-36762043

Bukhari S and Masroor R (2016) Mehbooba Mufti: Kashmir's first woman chief minister. BBC News, 4 April 2016. Available at: http://www.bbc.com/news/world-asia-india 30585105

Brosius HB and Weimann G (1996) Who sets the agenda: Agenda-setting as a two-step flow. Communication Research, 23(5): 561-580

Carruthers S (2000) The Media at War: Communication and Conflict in the Twentieth Century.

London: Macmillan

Cheema MJ (2015) Pakistan-India Conflict with Special Reference to Kashmir. South Asian Studies 30(1): $45-56$

Dasgupta P (2016). Was Burhan Wani And Why Is Kashmir Mourning Him? The Huffington Post, 11 July 2016. Available at: http://www.huffingtonpost.in/burhan-wani/who was burhan wani andwhy-is-kashmir-mourning-him

Entman RM (1993) Framing: Toward clarification of a fractured paradigm.

Geelani G ( 2016) Living in the shadow of curfew in Kashmir. BBC News, 5 Sep 2016. Availableat: http://www.bbc.com/news/world-asia-india-37211760

Gupta S (2019) To understand Modi's new Kashmir reality, these 5 liberal myths need to be broken. The Print, 17 Aug 2019. Available at: https://theprint.in/national interest/to understand-modis-new-kashmir-reality-these-5-liberal-myths-need-to be broken/278220/

Chandrachud, A (2019) The Abrogation of Article 370. Festschrift in Honour of Nani Palkhivala

Jammu and Kashmir: India formally divides flashpoint. (2019). BBC News. Available at: https://www.bbc.com/news/world-asia-india-50233281)

Khurshid $\mathrm{T}$ (2016) Fifth Generation Intifada in Indian Occupied Kashmir (IOK). Institute of Strategic Studies, Issue Brief. Available at : http://issi.org.pk/wp

Kaushal N (1997) Press and Democracy in India, in G H Peiris. Studies on the Press in Sri

Lanka and South Asia. Kandy, Sri Lanka: International Centre for Ethnic Studies: 53-79

Lynch and McGoldrick (2005) Peace Journalism. Gloucestershire: Hawthorn Press

Galtung J (1985) Twenty-five years of peace research: Ten challenges and some responses. Journal of Peace Research 22(2): 141-158.

Galtung J (1986) On the role of the media in worldwide security and peace. Peace and communication. San Jose, Costa Rica: Universidad para La Paz, 12-34.

Galtung J (1998) Peace Journalism: What, Why, Who, How, When, Where, paper presented at the workshop, What are Journalists For? TRANSCEND Taplow Court, 3-6 September.

Geelani G ( 2016) Living in the shadow of curfew in Kashmir. BBC News, 5 Sep 2016. Availableat http://www.bbc.com/news/world-asia-india-37211760

Gupta S (2019). To understand Modi's new Kashmir reality, these 5 liberal myths need tobe 
broken. The Print, 17 Aug. Available at: https://theprint.in/national interest/to understand-modisnew-kashmir-reality-these-5-liberal-myths-need-to be broken/278220/

Hanitzsch T (2004) Journalists as peacekeeping force? Peace Journalism and MassCommunication Theory. Journalism Studies 5(4): 483-495

Lee T, Seow and Maslog C (2004) War or peace journalism? Asian newspaper coverage of conflicts. Paper presented at the International Communication Association, New Orleans, LA.

Lecheler S and De Vreese CH (2011) Getting real: The duration of framing effects. Journal of Communication 61(5): 959-983.

Lynch and McGoldrick (2005) Peace Journalism. Gloucestershire: Hawthorn Press

Lynch J and Galtung J (2010) Reporting Conflict: new directions in peace journalism. Australia: University of Queensland Press

Manoff RK (1998) Telling the Truth to Peoples at Risk: Some Introductory Thoughts on Media and Conflict. The Legitimacy of Intervention for Peace by Foreign Media in a Country in Conflict , 2-4 July

Maslog CC, Lee ST and Kim SH (2006) Framing Analysis of a Conflict: How Newspapers in Five Asian Countries Covered the Iraq War. Asian Journal of Communication 16 (1): 19-39

Manoff RK (1998) Telling the Truth to Peoples at Risk: Some Introductory Thoughts on Media and Conflict. The Legitimacy of Intervention for Peace by Foreign Media in a Country in C Conflict, 2-4 July. Available at http://www. nyu. edu/globalbeat/pubs/manoff0798. html.

McCombs M and Shaw DL (1972) The Agenda-Setting Function of Mass Media. Public Opinion Quarterly 36: 176-187

McGoldrick A and Lynch J (2000) Peace Journalism. Available at https://www.transcend.org/tri/downloads/McGoldrick_Lynch_Peace-Journalism.pdf

Moeller SD (2004) Media coverage of Weapons of Mass Destruction.

Nixon R (1992) Seize the Moment: America's Challenge in a one-superpower World. New York:Simon and Schuster

Outrage over right-wing Euro-MPs' Kashmir visit. (2019). BBC News. Available at https://www.bbc.com/news/world-asia-india-50231022

Press Reference (2009) Press Reference Pakistan. Available at $\quad$ http://www.pressreference.com/No-

$\underline{\text { Sa/Pakistan.html }}$

Rao P (2016) Online Radicalization: The Example of Burhan Wani. IDSA Issue brief. $\quad$ Available at: http://www.idsa.in/system/files/issuebrief/ib_online radicalisation.pdf

Schlesinger P (1987) Putting reality together. London: Methuen

Scheufele D A (1999) Framing as a theory of media effects. Journal of communication 49(1): 103 122.

Shaw M, Weaver DH and Mc Combs M (1997) Communication and democracy: Exploring the intellectual frontiers in agenda-setting theory. Psychology Press.

Sigal LV (1973) Reporters and Officials. Lexington, MA: DC Heath

Sonwalkar P (2005) Banal Journalism: The centrality of the -us-them binary in news discourse ' in

Allan, S (ed). Journalism: Critical Issues. Berkshire: Open University Press, pp. 261273

Sreedharan C (2009) Reporting Kashmir: an analysis of the conflict coverage in Indian and

Pakistani newspapers. Doctoral dissertation: Bournemouth University.

Tehranian M (2002) Peace Journalism: negotiating global media ethics. Harvard International Journals of Press/Politics 7(2): 58-83.

The Indian Express (2016) BJP bats for establishment of Sainik Colony in Kashmir, May 28. Available at: http://indianexpress.com/article/india/india-news india/mehbooba muftijammu kashmir-sainik-colony-bjp-national-secretary shrikant sharma-kashmiri pandits-2823664/ UN News (2019) UN Security Council discusses Kashmir, China urges India and Pakistan to ease tensions, Aug 16. Available at : https://news.un.org/en/story/2019/08/1044401 Viswanath K \& Karan K (2000) India, in S A Gunaratne (ed). Handbook of the Media in Asia. London: Sage 
Wolfe T and Johnson EW (1990) New Journalism. Basingstoke: Picador.

Wolfsfeld G (2004) The Media and Path to Peace. Cambridge: Cambridge University Press.

Yasir S and Gettleman J (2019) Anxious and Cooped Up, 1.5 Million Kashmiri Children Are

Out of School. New York Times,31 Oct .Av

Zaheer L (2017) Editorial Coverage of Kashmir Conflict in Pakistani Media. Pakistan Vision, 18(1). 


\section{Coding Sheet}

\section{V1-Newspaper}

1=Dawn 2=The Nation 3=Times of India 4=The Hindu

V2-Source of Story

$1=$ Staff reporter 2=News Agencies

4=Local

correspondents/Freelancers

$5=$ Reprinted from other publications $6=$ Other

V3- War frames

War A1=violence oriented $(1=$ Yes, $2=$ No)

War A2= Propaganda Oriented $(1=$ Yes, $2=$ No $)$

War A3= Elite source Oriented $(1=$ Yes, $2=\mathrm{No})$

War A4= Zero-Sum Oriented (1=Yes, 2=No)

V4-Peace Frames

Peace $A 1=$ peace oriented $(1=$ Yes, $2=$ No)

Peace $A 2=$ Truth Oriented $(1=$ Yes, $2=\mathrm{No})$

Peace A3 $=$ Multiple source oriented $(1=\mathrm{Yes}, 2=\mathrm{No})$

Peace A4=Solution-oriented (1=Yes, 2=No)

V5-Neutral Frame (1=Yes, 2=No)

V6-Frames which are present in majority

(1=War Frames, 2=Peace Frames, 3=Neutral Frames) 